\title{
Operational meteorology in West Africa: observational networks, weather analysis and forecasting
}

\author{
Andreas H. Fink, ${ }^{1}$ * Anna Agustí-Panareda, ${ }^{2}$ Douglas J. Parker, ${ }^{3}$ Jean-Philippe Lafore, ${ }^{4}$ Jean-Blaise Ngamini, ${ }^{5}$ \\ Ernest Afiesimama, ${ }^{6}$ Anton Beljaars, ${ }^{2}$ Olivier Bock, ${ }^{7}$ Michael Christoph,' ${ }^{\prime}$ rancis Didé, ${ }^{8}$ Claudia Faccani, ${ }^{4}$ \\ Nadia Fourrié, ${ }^{4}$ Fatima Karbou, ${ }^{4}$ Jan Polcher, ${ }^{9}$ Zilore Mumba, ${ }^{10}$ Mathieu Nuret, ${ }^{4}$ Susan Pohle, ${ }^{\prime}$ Florence Rabier, ${ }^{4}$ \\ Adrian M. Tompkins' ${ }^{\prime \prime}$ and George Wilson ${ }^{12}$ \\ I Institute of Geophysics and Meteorology, University of Cologne, Cologne, Germany \\ ${ }^{2}$ ECMWF, Reading, UK \\ ${ }^{3}$ School of Earth and Environment, University of Leeds, UK \\ ${ }^{4}$ CNRM-GAME, Météo-France \& CNRS, Toulouse, France \\ ${ }^{5}$ ASECNA, Dakar, Senegal \\ ${ }^{6}$ NIMET, Abuja, Nigeria \\ ${ }^{7}$ IGNILAREG and IPSL/LATMOS, Paris, France \\ ${ }^{8}$ DMN Bénin, Cotonou, Bénin \\ ${ }^{9}$ LMD/IPSL/CNRS, Paris, France \\ ${ }^{10}$ ACMAD, Niamey, Niger \\ 1 ICTP, Trieste, Italy \\ ${ }^{12}$ GMA, Accra, Ghana
}

* Correspondence to:

Andreas H. Fink, Institute of Geophysics and Meteorology,

University of Cologne, Kerpener

Str. 13, D-50923

Cologne, Germany.

E-mail: fink@meteo.uni-koeln.de

Received: 9 February 2010

Revised: I November 2010

Accepted: II December 2010

\begin{abstract}
Real-time surface and upper-air observations are crucial to the analysis and forecasting of the West African monsoon (WAM). This paper will focus on the African Monsoon - Multidisciplinary Analyses (AMMA)-driven reactivation and modernisation of the radiosonde network over West Africa, its potential long-term impact on upper-air operations in the region, the influence of the additional data in WAM analyses and forecasting, and the AMMA-related development and usage of the West African Analysis/Forecasting (WASA/F) forecast method. Copyright $\odot 2011$ Royal Meteorological Society
\end{abstract}

Keywords: West Africa; radiosonde network; weather analysis; forecasting

\section{Introduction}

Real-time, in situ, and remote surface and upper-air observations are crucial to the analysis and forecasting of the West African monsoon (WAM). Beyond these benefits in day-to-day weather forecasting, an observational network, well-maintained over many years, allows for the compilation of high-quality (re-)analysis data sets, thereby supporting process, climate, and model validation studies. Despite the advent of many satellite sensors in the last four decades, whose data are assimilated in operational analyses, surface station data and upper-air information from radiosondes remained an essential source of information over land for weather forecast models mainly for the following reasons (Tompkins et al., 2005; Faccani et al., 2009; Agustí-Panareda et al., 2010a): (1) usage of satellite data is still predominantly limited to cloud-free pixels; (2) satellites provide indirect information with a relatively coarse vertical resolution; and (3) a hitherto very limited use of satellite channels with peak sensitivity in the lower troposphere, due to the heterogeneous surface emissivity. As a consequence, present-day radiosonde systems that provide digital in situ wind, temperature, pressure, and humidity data at a high vertical resolution, permit the best possible definition of the (thermo-)dynamic state of the troposphere, especially at lower levels. The determination of the state of the atmosphere in the lowest few kilometres in the WAM region is of pivotal importance since it is the low-level vertical profiles of temperature, humidity and wind that favour or disfavour the organisation of West African rainy systems and that are crucial for determining the influx of moisture from the surrounding oceans.

Operational and maintenance costs of radiosonde networks are, however, very high and the (West) African radiosonde network has been degrading over many years before the African Monsoon Multidisciplinary Analyses (AMMA) programme was launched in 2002 ( $c f$ Parker et al., 2008). The complete lack of operating radiosonde stations in the important monsoon inflow zone south of $10^{\circ} \mathrm{N}$, upstream of the African Easterly Jet (AEJ) east of $10^{\circ} \mathrm{E}$, and in the northern Sahel between $15^{\circ} \mathrm{N}$ and $20^{\circ} \mathrm{N}$ (Figure 1) was identified as a major risk to the successful achievement of AMMA scientific goals (Polcher et al., 2011). Beyond the support of AMMA's 


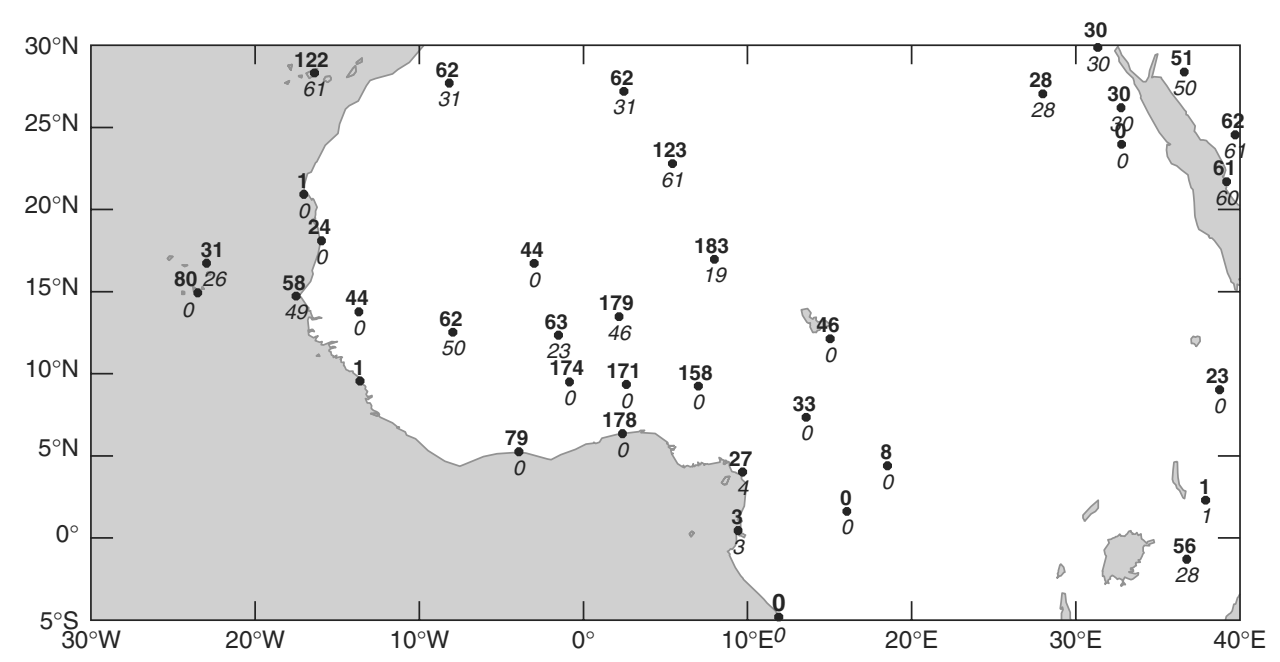

Figure I. Number of soundings received on the GTS in August 2006 from stations and synoptic times representative of the 2005 (pre-AMMA) operational radiosonde network (numbers in italics) and AMMA Special Observing Period soundings in August 2006 (numbers in boldface).

scientific goals, the AMMA-funded refurbishment and enhancement of the radiosonde network pursued two further aims: (1) to support local agencies in updating/refurbishing existing stations, establishing new stations, and training their staff; and (2) to evaluate the optimal network for Numerical Weather Prediction (NWP) and climate monitoring by, for example, performing Observing System Experiments (OSEs). The achievements of AMMA in terms of the latter two goals are one focus of the present paper.

While the operation and exploitation of radiosonde and part of surface data for aviation purposes in the West African francophone countries (except Guinea) is managed by Agence pour la Sécurité de la Navigation Aérienne en Afrique et à Madagascar (ASECNA), the National Weather Services (NWS) run the surface meteorological networks and are responsible for issuing weather forecasts at the national level. This unique organisational structure is one of the many reasons for the large diversity in financial and technical facilities across West African analysis and forecasting centres. A typical use of upper-air data has been the manual streamline analyses at metric height levels (e.g. 600, 900, 1500, and $2100 \mathrm{~m}$ ). Combined with surface wind and dewpoint-based analyses of the Intertropical Discontinuity (ITD) location, these charts formed the basis for nowcasting at ASECNA and NWS centres until very recently. This situation was improved at many NWS headquarters by the European Organisation for the Exploitation of Meteorological Satellites (EUMETSAT)-funded installation of Preparation for Use of MSG in Africa (PUMA) satellite receiving stations. At the African Centre of Meteorological Application for Development (ACMAD) (Niger) another source of weather charts was through the Mété-France Forecasting Synergie System fed by the Reseau de Transmission d'Information Météorologique (RETIM)-Afrique transmission link. However, before the arrival of
AMMA, forecasters often lacked a modern conceptual framework for analysing and forecasting the major synoptic features of the WAM. Thus, another focus of the present contribution will be the description of the West African Synthetic Analysis/Forecasting (WASA/F) method developed within AMMA.

In Section 2, the successes, failures, and potential long-term operational impacts of the refurbished West African radiosonde network is discussed. Section 3 is dedicated to the impact of the additional data on WAM analyses and forecasting. In Section 4, the principal approach of WASA/F is introduced and Section 5 provides a conclusion.

\section{The AMMA radiosonde campaign: successes, problems, and long-term operational impacts}

The dilapidated state of the West African radiosonde network before AMMA and the multi-faceted challenges faced to refurbish, re-activate, and to establish new upper-air stations has been described in detail in Parker et al. (2008). Some salient successes of the AMMA campaign were the - at least temporary - reactivation of long-silent stations [e.g. Tamale (Ghana, inactive since 1981), Abidjan (Ivory Coast, silent since 2001), Ngaoundere (Cameroon, almost no data feeding into the Global Telecommunication System, GTS), Conakry (Guinea), and Tessalit (Mali, became active in 2007 and 2008)], as well as the establishment of three new stations in the coastal inflow zone, viz. Cotonou and Parakou (both Benin) and Abuja (Nigeria). The enhanced station network operational in August 2006 is evident from Figure 1. For the 2 years 2006 and 2007, a unique spatial and temporal density of highly resolved (vertically every $5-10 \mathrm{~m}$ ) sounding data are available for the WAM region. Between 2005 and 2009, some 13,500 high-resolution 
soundings are stored in the AMMA database (http:// amma-international.org/database; Fleury et al., 2011).

Some major problems and shortcomings are also worthy of note. In common with meteorological services worldwide, the African partner agencies in AMMA had to introduce commercial competition with the radiosonde equipment suppliers. This was one reason for the deployment of various sonde types during the AMMA campaign, each of which has its unique, time of day-dependent biases in relative humidity measurements. The Vaisala RS80-A sondes were known for having large dry biases; biases of Vaisala RS92 are weakly moist at night and significantly dry during the daytime; whereas the humidity biases of the French MODEM M2K2 sondes were unknown. The evaluation of radiosonde humidity observations from the 2006 Special Observing Period of AMMA (SOP) with independent Global Positioning System (GPS) estimates of the total column water vapour allowed the documentation of those biases (Bock et al., 2008). Owing to the importance of vertical humidity profiles for the convective activity and WAM water budget, large efforts were undertaken to correct the humidity errors. For that aim two methods have been developed. Nuret et al. (2008) propose a statistical humidity bias correction scheme as a function of temperature and humidity. In a first step, only RS80-A soundings were corrected according to Nuret et al.'s method; their correction was tuned against Vaisala RS92 information at night which is believed to be the most reliable available operational sonde type at night. This corrected RS80-A dataset is available in the AMMA database. At the time of writing, reference soundings at Niamey from Swiss Meteolabor SnowWhite sondes (Verver et al., 2006) are used to correct all other sonde types. A final corrected dataset should be available by 2011. Another correction scheme is proposed by Agustí-Panareda et al. (2009); a statistical method estimates the bias correction as a function of humidity, solar elevation angle, sonde type, and vertical pressure using the European Centre for Medium-Range Weather Forecasts (ECMWF) model first guess and RS92 soundings at night as a reference. They have developed correction functions for all radiosonde types (RS80-A, RS92, and M2K2). As this last method depends both on the no-biased RS-92 assumption at night and on the model's own bias, a substantial degree of uncertainty in low-level moisture profiles and AMMA reanalyses still persists.

In terms of the long-term operational impacts of the AMMA campaign, it can be stated that the upgrade of ASECNA's Vaisala ground stations funded by AMMA enabled the network to make the transition to the new digital sonde generation and likely avoided its collapse with the end of the production of the analogue version in 2005 (Parker et al., 2008). The AMMA project also supported ASECNA to improve their launching facilities [e.g. balloon inflation halls, hydrogen generators, (satellite) communication links] at several stations (e.g. Dakar, Abidjan, and Douala)

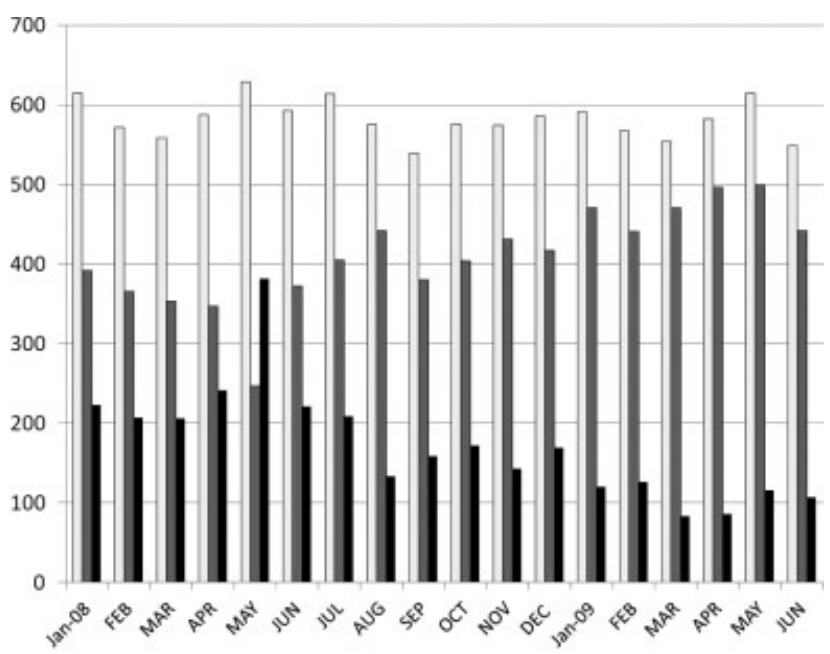

Figure 2. Number of monthly soundings made on ASECNA's 'AMMA' stations in the period January 2008-June 2009 (open bars), with number of messages received at ECMWF (grey bars) and numbers missing (black bars).

and to conduct training of the station staff. This has undoubtedly contributed to the high success rate of ASECNA's AMMA soundings in the post-Extensive Observing Period of AMMA (EOP, 2005-2007) era from January 2008 to June 2009 (Figure 2). However, as is evident from Figure 2, some $30 \%$ of TEMP messages from these reliable stations are still lost due to persistent GTS failure - a problem out of the scope of the AMMA project. Moreover, even though the AMMA-activated stations in the wetter coastal area (e.g. Tamale, Parakou, Cotonou, and Abuja) performed soundings beyond the end of the AMMA EOP, these stations gradually become moribund when consumables faded out in 2008.

\section{Impact of the additional data on WAM analyses and forecast}

The additional radiosondes during the 2006 intensive observing campaign had a positive impact on the ECMWF and French WAM analyses and forecast after the humidity was corrected using the method described in Agustí-Panareda et al. (2009). For the French NWP system, this is shown in Faccani et al. (2009) whereas for the ECMWF analysis system, this was investigated by Agustí-Panareda et al. (2010a) by running two data assimilation experiments for August 2006. The first is the AMMA re-analysis (AgustíPanareda et al., 2010b) in which all the additional data are included. They consist of data received at ECMWF via the GTS and e-mail during the field campaign and those furnished to ECMWF after the experiment. The second experiment is the 'pre-AMMA scenario' in which the additional sondes are deleted such that a typical coverage as in 2005 is obtained ( $c f$ Figure 1). Since all the other aspects of the system are the same (e.g. same model version, same resolution) any impact can only be due to data coverage. 

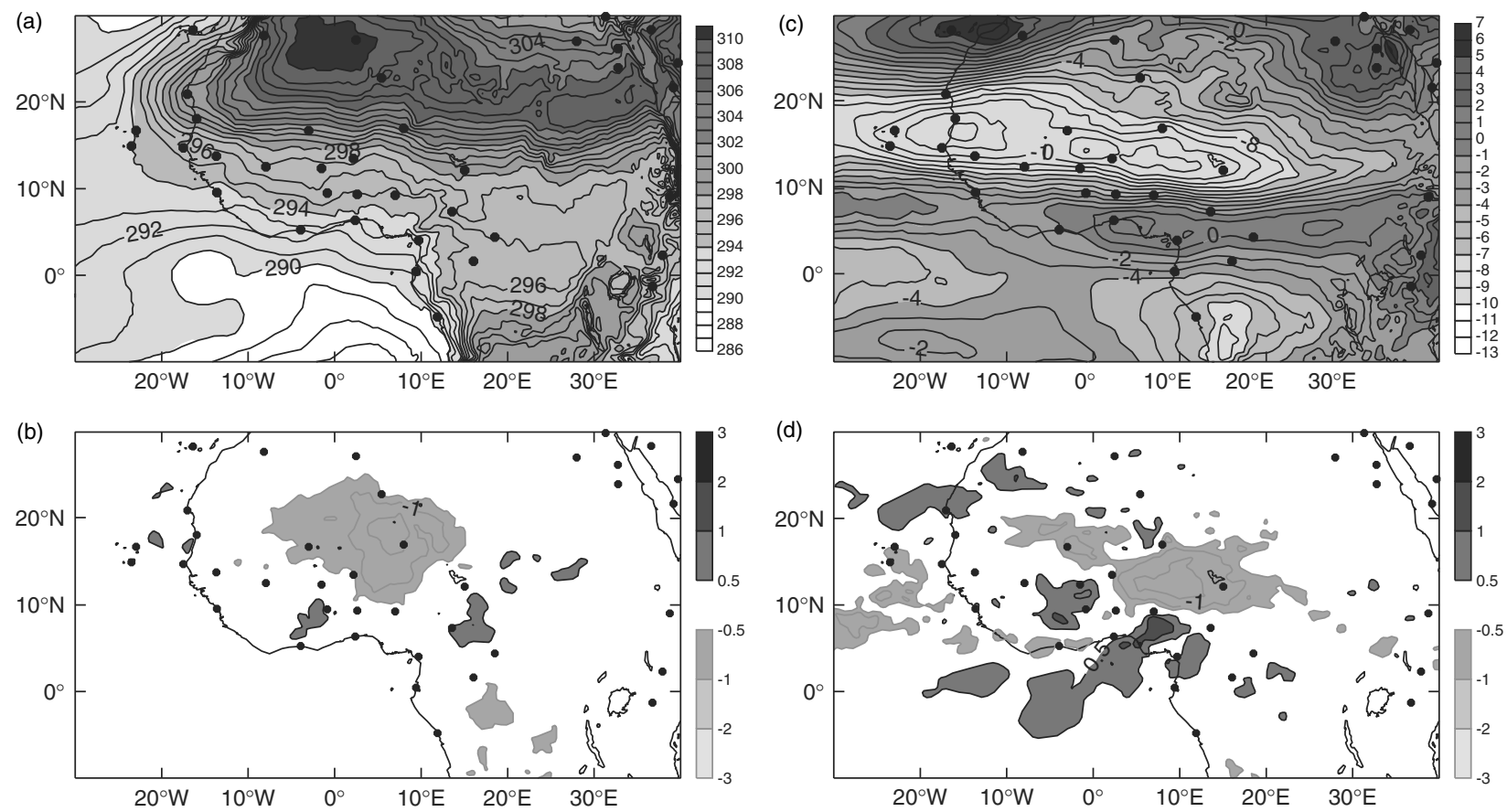

Figure 3. Mean temperature (K) at $925 \mathrm{hPA}$ (a) and the zonal mean wind speed (m/s) at $700 \mathrm{hPa}$ (c) for August 2006 based on 0000 and 1200 UTC analyses from the AMMA re-analysis. The bottom panels are temperature difference (b) and wind speed difference (d) between the AMMA/re-analysis and the pre-AMMA experiment. The black dots indicate the location of the AMMA radiosonde stations (after Agusti-Panareda et al., 2010a). (c) American Meteorological Society. Reprinted with permission.

Figure 3 shows the effect of the additional sondes on the analysis of temperature at 925 and zonal wind at $700 \mathrm{hPa}$, respectively. The mean temperature in AMMA is around $2 \mathrm{~K}$ cooler than in pre-AMMA in the vicinity of Agadez $\left(7.98^{\circ} \mathrm{E} / 16.97^{\circ} \mathrm{N}\right)$ and extends over the region between $5^{\circ} \mathrm{W}-15^{\circ} \mathrm{E}$ and $10^{\circ} \mathrm{N}-25^{\circ} \mathrm{N}$ (Figure 3(b)). The implication is that the sharp temperature gradient between Sahel and Sahara shifts north. Further study by Agustí-Panareda et al. (2010a) shows that the monsoon flow is also significantly different in the two analyses, with slower wind speeds in the AMMA re-analysis. A key feature of the West African monsoon is the AEJ, well known for its interactions with WAM convective systems and its role in the North Atlantic tropical cyclogenesis through the development of African Easterly Waves (AEWs). Also on this aspect, the two analyses are rather different as illustrated by the zonal wind speed at $700 \mathrm{hPa}$ in Figure 3. In the AMMA experiment, the jet streak extends east of $10^{\circ} \mathrm{E}$ (Figure 3(c)) whereas in pre-AMMA the easterly winds in the jet entrance region $\left(5^{\circ} \mathrm{E}-15^{\circ} \mathrm{E}\right)$ are weaker by approximately $2 \mathrm{~m} / \mathrm{s}$ (Figure 3(d)). A similar finding has been noted by Faccani et al. (2009), who assimilated the AMMA radiosonde data using the Météo-France ARPEGE4D-Var system for the period 15 July-15 September 2006. It became also clear, however, that, despite the enhanced network, analysis deficits persisted due to data gaps and assimilation problems. For instance, independent atmospheric motion vectors show that the African easterly jet core extends as far east as the Red Sea (Agustí-Panareda et al., 2010a) and from the moisture budget study by Meynadier et al. (2010) it can be concluded that the AMMA analysis does not constrain the moisture convergence very well in the Sahel in spite of the extra observations.

One of the most important parameters to forecast during the monsoon season is precipitation. The impact of the extra AMMA radiosondes on the oneday precipitation forecast in the ECMWF analyses system is to increase the precipitation amount by $\sim 2 \mathrm{~mm} /$ day over the central Sahel (around the Greenwich meridian) and to decrease the precipitation in the eastern part (east of 10E, for more details see Agustí-Panareda et al., 2010a). This decrease is not good because it occurs over a region where there was already a deficit of precipitation (e.g. compared to Global Precipitation Climatology Project analysis). This seems to be partly linked to the fact that observations east of $10^{\circ} \mathrm{E}$ are sparse and the analysis increments are localised, producing an unrealistic local circulation with divergence and subsidence as a result of the large cooling around the radiosonde stations (e.g. Ndjamena). Subsiding motion constitutes a deterrent for the triggering of convection.

Several experiments were run using the French NWP system. The experiment without the stations constituting the AMMA radiosonde network is clearly not performing as well as the other experiments, which means that a basic radiosonde network is needed. However, the impact of the AMMA soundings is further improved if the ECMWF bias correction is applied to the relative humidity measurements. Thus, forecasts running from the AMMA analyses are indeed better for the WAM region than the ones from the preAMMA analyses, but the advantage is lost over West 


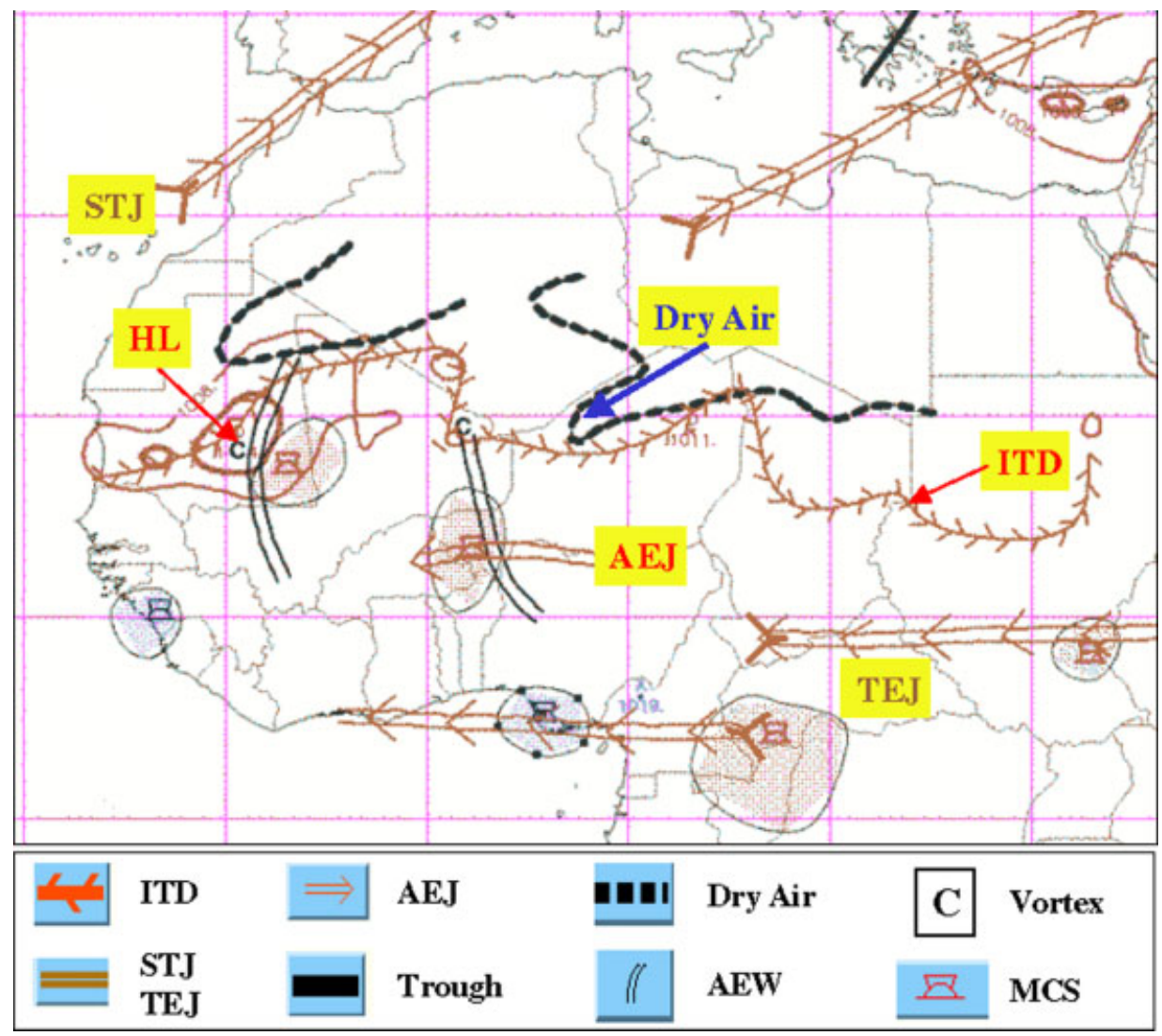

Figure 4. Illustration of the different key features, present on the WASA/F map of 19 July 20060600 UTC. Regions affected by organized mesoscale convective systems are hatched in brown and blue, the latter colour indicating decaying systems. Brown contours denote the 1008 and $1006 \mathrm{hPa}$ (in bold) surface isobars, respectively to indicate the position of the West African heat low (for more details see text).

Africa within $24 \mathrm{~h}$, although there is a positive impact over Europe after 2-3 days in the French system (Faccani et al., 2009; Agustí-Panareda et al., 2010a).

Even with additional radiosondes, the network is still far from being optimal over Africa. OSEs during the summer 2006 by Karbou et al. (2010a, 2010b) with and without the assimilation of Advanced Microwave Sounding Unit (AMSU)-A and AMSU-B channels close to the surface over the continent demonstrated an important improvement of analyzed fields and of precipitation forecasts over parts of the Tropics and especially over West Africa, as validated with AMMA observations. Physically, the changes result in a better-organized African monsoon with a stronger Intertropical Convergence Zone (ITCZ) in terms of ascent, vorticity, and precipitation. Forecast errors were reduced over the Tropics, leading to significant forecast improvements at higher latitudes at 48 and 72-h ranges.

\section{The West African synthetic analysis/forecast}

The task of a forecaster involves the analysis of numerous observations and NWP products (both analysis and forecasts) before deciding on the weather forecast for a given location and range. This is a very complex process involving both objective and subjective criteria and where the experience of the forecaster plays an important role on the skill of the final forecast. The difficulty is even stronger for tropical regions where in contrast to mid-latitudes the atmospheric flow is weakly balanced resulting in a weaker predictability, especially for convective events. This forecast process needs to be performed as quickly as possible and needs to be synthesised into a form which can be understood by non-specialist users and customers. With the development and implementation of the WASA/F method, AMMA again pursued a dual strategy: (1) to fulfil the operational forecast needs for the campaign in 2006, thereby, supporting the achievement of the scientific objectives; and (2) to develop a forecasting method with experienced African forecasters that could be adopted as an operational tool at African weather centres, simply because it provides guidance to the forecaster through the above-mentioned complex forecasting process.

The proposed forecasting approach is based on the preparation of single synthetic maps that summarize all key features of the WAM analyzed or forecast at a given time. The following ten features are considered important and are drawn on the WASA/F maps in order to capture the main synoptic flow and mesoscale convective features of the situation and to forecast the weather (Figure 4). These are 
(1) the ITD; (2) the associated heat low (HL); (3) the Subtropical Jet (STJ) and, if present, the Polar Jet (PJ); (4) associated trough axes extending from midlatitudes; (5) the Tropical Easterly Jet (TEJ); (6) the $\mathrm{AEJ}$; (7) troughs and cyclonic centres associated with AEWs (see AEW trough and ' $C$ ' character over southeastern Mauritania in Figure 4); (8) mid-level dry air boundaries (black dashed line in Figure 4); (9) the monsoon layer for which forecasters have to plot specific maps at 950 and $850 \mathrm{hPa}$ to analyze its characteristics (depth, moisture content); and (10) convective activity with the distinction of the three cases of suppressed convection areas, unorganized isolated convective cells (both not present in Figure 4), and Mesoscale Convective Systems (MCSs) (see cumulonimbus signs in Figure 4), or Squall Lines (SLs) (not present in Figure 4).

The first nine key features were provided during AMMA SOP by NWP outputs from different centres, e.g. ECMWF, Météo-France, National Centers for Environmental Prediction (NCEP), and UK Met Office. They were available at ACMAD (Niger) and on a web site specifically developed for the AMMA Operational Centre (http://aoc.amma-international.org/) that also included observations and research products to monitor the WAM at different scales. Using a synthesis of the above-mentioned NWP products, these nine key features were drawn by the forecaster according to some rules using computer software. The model skill to forecast convective activity is poor in such tropical regions, so that the final forecast of MCSs is the result of the combination of all the above nine features, following some rules. For instance, active fast-moving MCSs are known to be favoured by convective instability, high precipitable water, sufficient vertical shear (often present in the AEJ region), mid-level dry air, and the proximity of a (AEW) trough or vortex in the 700-850-hPa layer. A bilingual forecaster's guide of the WASA/F method has been written and is available from ACMAD's website (http://aocafrique.ammainternational.org/dir.php?current $=20100211 \& \mathrm{dir}=$ archive/reports/forecast/forecastguide\&sort=date \& order $=$ asc $\&$ nav $=$ Forecast $\% 20$ reports). The SOP 2006 summer demonstration experiment showed that the WASA/F systems helped the forecasters to capture the synoptic situation and to create a synthesis forecast. However, it appeared that the method needs to be improved to define clearer drawing rules based on adequate and objective diagnostics. It concerns primarily AEWs and related troughs, dry air boundaries, and a way to summarize the main characteristics of the monsoon layer. Finally, it shall be mentioned that Météo-France made available in real-time MCS tracking products derived from Meteosat infrared images developed within the framework of EUMETSAT's Satellite Application Facilitites (SAF) Nowcasting (Morel and Sénési, 2002). This product has been very useful to monitor the convection activity both for forecasters and scientists, and is still used at ACMAD.

\section{Conclusions}

A unique feature of AMMA has certainly been the leading involvement of ASECNA and some NWSs in carrying out operational and research soundings in West Africa. This was a major pillar of the success in the enhancement of upper-air data in the WAM region between 2005 and 2009 and has greatly contributed to the success of the AMMA field campaign. The assimilation of the additional, humidity bias-corrected sonde data led to a distinct improvement in the analyzed atmospheric fields, in the sense that the analyses are closer to observations. The unique AMMA database comprising the soundings and the AMMA re-analysis is of unprecedented quality and has been proven to be very valuable for WAM process and model studies. This will remain so in the coming years.

The forecasts started from the AMMA re-analyses lost the advantage within the first $24 \mathrm{~h}$ over West Africa. As a consequence, it is at present impossible to define an optimal radiosonde network for NWP in West Africa due to model biases in the short range forecasts. Forecast quality depends on the quality of observations, of the data assimilation, as well as of the models. This calls for both an optimal observation network, as well as for data assimilation and model improvements. Regarding the latter, the process and model studies within AMMA (Lafore et al., 2011; Ruti et al., 2011) have provided the research avenue. Also, more research is needed in data assimilation and the use of alternative data. Progress in this direction can be expected from use of cloud motion winds, the assimilation of rain rates and a more aggressive use of satellite radiances over land and in cloudy areas. In the latter context, a recent step to improve lowlevel moisture analyses and rainfall forecasts over tropical monsoon regions has been achieved using Medium Resolution Imaging Spectrometer (MERIS) and AMSU microwave channels, respectively (Bauer et al., 2009; Karbou et al., 2010a, 2010b).

The AMMA project clearly demonstrated that a good observation network is a minimum condition for making progress towards improving process understanding and models. Direct measurements will always be needed due to their high vertical resolution and use in the calibration of satellite retrieval algorithms. Given the likely model improvements emerging from ongoing AMMA research, there is a persisting need to determine an optimal, cost-effective radiosonde network. To achieve this goal, a longer, multi-year period is necessary in which the (West) African radiosonde network performs at a spatial density and temporal sounding frequency comparable to the networks in Europe, North America, and East Asia. AMMA demonstrated that the radiosonde network can be as strong as in these other regions of the world. Such a network would have other benefits such as climate change monitoring in a continent that is thought to be very vulnerable to the projected climate changes. The 
radiosonde network will, however, decay further in the coming years without a structural change in the international management. As part of this, it is necessary to improve the quality, value, and training in use of NWP products for local meteorological agencies which will then motivate better collection and communication of data.

ACMAD has developed the WASA/F method somewhat further to capture North African dry season features like slight to moderate dust or haze zones. WASA/F maps are currently operationally produced at $\mathrm{ACMAD}$ and available through their website (http://www.acmad.ne/en/prevision/short_range.pdf).

ACMAD is also involved in WMO severe weather forecasting demonstration project (SWFDP, http:// www.un-spider.org/guide-en/3220/severe-weatherforecasting-demonstration-project-swfdp) such as for southern Africa. Within this context South African Synthetic Analysis/Forecasting (SASA/F) maps are currently being developed and tested. Thus, AMMA kicked off and steered the transfer and development of a new analysis and forecasting method for all seasons and the entire African continent. Currently, a Handbook for Forecasters in West Africa is being compiled in which AMMA consortium members play a leading role. However, the further development of WASA/F and SASA/F after AMMA is not guaranteed. The value of this new method needs to be better recognized in the region and internationally. It is to be hoped that these initiatives to systematically improve the operational use of NWP products in Africa will have a positive influence on data collection and communication by the local meteorological agencies.

\section{Acknowledgements}

The support of the AMMA project is gratefully acknowledged (see http://onlinelibrary.wiley.com/doi/10.1002/asl.331/full for full acknowledgement).

\section{References}

Agustí-Panareda A, Beljaars A, Cardinali C, Genkova I, Thorncroft C. 2010a. Impact of assimilating AMMA soundings on ECMWF analyses and forecasts. Weather and Forecasting 25: 1142-1160. DOI: $10.1175 / 2010$ WAF2222370.1

Agustí-Panareda A, Beljaars A, Ahlgrimm M, Balsamo G, Bock O, Forbes R, Ghelli A, Guichard F, Koehler M, Meynadier R, Morcrette JJ. 2010b. The ECMWF re-analysis for the AMMA observational campaign. Quarterly Journal of Royal Meterological Society 136: $1457-1472$.

Agustí-Panareda A, Vasiljevic D, Beljaars A, Bock O, Guichard F, Nuret M, Garcia Mendez A, Andersson A, Bechtold P, Fink A, Hersbach H, Lafore JP, Ngamini JB, Parker DJ, Redelsperger JL, Tompkins AM. 2009. Radiosonde humidity bias correction over the West African region for the special AMMA reanalysis at ECMWF. Quarterly Journal of Royal Meterological Society 135: 595-617.

Bauer P. 2009. 4D-Var assimilation of MERIS total column water vapour retrievals over land. Quarterly Journal of Royal Meterological Society 135: 1852-862.
Bock O, Bouin MN, Doerflinger E, Collard P, Masson F, Meynadier R, Nahmani S, Koité M, Gaptia Lawan Balawan K, Didé F, Ouedraogo D, Pokperlaar S, Ngamini JB, Lafore JP, Janicot S, Guichard F, Nuret M. 2008. The West African Monsoon observed with ground-based GPS receivers during AMMA. Journal of Geophysical Research 113: D21105. DOI: 10.1029/2008JD010327

Faccani C, Rabier F, Fourrié N, Agustí-Panareda A, Karbou F, Moll P, Lafore JP, Nuret M, Hdidou FZ, Bock O. 2009. The impact of the AMMA radiosonde data on the French global assimilation and forecast system. Weather and Forecasting 24: 1268-1286.

Fleury L, Boichard JL, Brissebrat G, Cloché S, Eymard L, Mastrorillo L, Moulaye O, Ramage K, Asencio N, Coppeaux J, Devic MP, Favot F, Ginoux K, Lafore JP, Polcher J, Redelsperger JL, Roussot O, Tytéca M. 2011. AMMA information system: an efficient cross-disciplinary tool and a legacy for forthcoming projects. Atmospheric Science Letters 12: 149-154, DOI: 10.1002/asl.303.

Karbou F, Gérard E, Rabier F. 2010a. Global 4D-Var assimilation and forecast experiments using AMSU observations over land. Part-I: impact of various land surface emissivity parameterizations. Weather and Forecasting 25: 5-19.

Karbou F, Rabier F, Lafore JP, Redelsperger JL, Bock O. 2010 b. Global 4D-Var assimilation and forecast experiments using AMSU observations over land. Part II: impact of assimilating surface sensitive channels on the African Monsoon during AMMA. Weather and Forecasting 25: 20-36.

Lafore J-P, Flamant C, Guichard F, Parker DJ, Bouniol D, Fink AH, Giraud V, Gosset M, Hall N, Höller H, Jones SC, Protat A, Roca R, Roux F, Saïd F, Thorncroft C. 2011. Progress in understanding of weather systems in West Africa. Atmospheric Science Letters 12: 7-12, DOI: 10.1002/asl.335.

Meynadier R, Bock O, Gevois S, Guichard F, Redelsperger JL, Agustí-Panareda A, Beljaars A. 2010. West African Monsoon water cycle. 2. Assessment of numerical weather prediction water budgets. Journal of Geophysical Research 115: D19107. DOI: 10.1029/2010JD013919

Morel C, Sénési S. 2002. A climatology of mesoscale convective systems over Europe using satellite infrared imagery. I: methodology. Quarterly Journal of Royal Meterological Society 128: 1953-1992.

Nuret M, Lafore JP, Bock O, Guichard F, Agustí-Panareda A, Ngamini JB, Redelsperger JL. 2008. Correction of humidity bias for Vaïsala RS80 sondes during AMMA 2006 Observing Period. Journal of Atmospheric and Oceanic Technology 25: 2152-2158.

Parker DJ, Fink AH, Janicot S, Ngamini JB, Douglas M, Afiesimama E, Agustí-Panareda A, Beljaars A, Dide F, Diedhiou A, Lebel T, Polcher J, Redelsperger JL, Thorncroft C, Wilson GA. 2008. The AMMA radiosonde program and its implications for the future of atmospheric monitoring over Africa. Bulletin of the American Meteorological Society 89: 1015-1027.

Polcher J, Parker DJ, Gaye A, Diedhiou A, Eymard L, Fierli F, Genesio L, Höller H, Janicot S, Lafore J-P, Karambiri H, Lebel T, Redelsperger J-L, Reeves CE, Ruti P, Sandholt I, Thorncroft C. 2011. AMMA's contribution to the evolution of prediction and decision-making systems for West Africa. Atmospheric Science Letters 12: 2-6, DOI: 10.1002/asl.320.

Ruti PM, Williams JE, Hourdin F, Guichard F, Boone A, Van Velthoven P, Favot F, Musat I, Rummukainen M, Domínguez M, Gaertner MA, Lafore JP, Losada T, Rodriguez de Fonseca MB, Polcher J, Giorgi F, Xue Y, Bouarar I, Law K, Josse B, Barret B, Yang X, Mari C, Traore AK. 2011. The West African climate system: a review of the AMMA model inter-comparison initiatives. Atmospheric Science Letters 12: 116-122, DOI: 10.1002/asl.305.

Tompkins AM, Cardinali C, Morcrette JJ, Rodwell M. 2005. Influence of aerosol climatology on forecasts of the African Easterly Jet. Geophysical Research Letters 32: L10801. DOI: 10.1029/2004GL022189

Verver G, Fujiwara M, Dolmans P, Becker C, Fortuin P, Miloshevich L. 2006. Performance of the vaisala RS80A/H and RS90 humicap sensors and the meteolabor "Snow White" chilled-mirror hygrometer in paramaribo, suriname. Journal of Atmospheric and Oceanic Technology 23: 1506-1518. 